\title{
The Transylvanian Party between 1940 and 1944 A Brief History
}

\author{
János Kristóf MURÁDIN \\ Department of European Studies, \\ Sapientia University, Cluj-Napoca \\ muradinjanoskristof@yahoo.com
}

\begin{abstract}
The paper deals with the theme of the Transylvanian Party [Erdélyi Párt], one of the most important Hungarian political formations in Transylvania in the $20^{\text {th }}$ century. After the reintegration of Northern Transylvania in the Hungarian state following the Second Vienna Arbitration, Hungarians became a majority in the region, established their own political party, the Transylvanian Party, with powerful local characteristics. The paper concentrates on the analysis of the Transylvanian Party, it presents its foundation, its representation in the Hungarian Parliament, and its relations with the Hungarian government. The paper tries to give an overview of the successes and failures of the party as well. Finally, the decline of the Transylvanian Party and its political heritage are presented. The source material of the paper consists of archival data, publications of the Transylvanian Party, special books, studies, articles of the contemporary press, and on-line publications.
\end{abstract}

Keywords: Second Vienna Arbitration, Northern Transylvania, integration, Transylvanian Party, members, local branches, deputies, parliament, party politics, political co-operation

The first steps to an independent Hungarian political life in Transylvania were taken at he beginning of the $19^{\text {th }}$ century, in the so-called 'Age of Reforms'. In these times, Hungarian leaders from Transylvania made speeches against Metternich's Regime and the Austrian domination at County Assemblies or Transylvanian Diets. But an autonomous Transylvanian Hungarian Party had not been founded yet. The situation did not change after the formation of the Austrian-Hungarian Monarchy in 1867 either, and the Hungarian deputies from Transylvania took part in large national parties: the 1848 Independence Party (48-as Függetlenségi Párt) or the Party of Free Principles (Szabadelvú Párt), trying to support the interests of their region in the Hungarian Parliament.

A modern, independent Transylvanian Hungarian political life could have begun only after the separation from the Hungarian state. The Treaty of 
Trianon made possible for the Transylvanians the creation of their own political formations, and, at the same time, it created an impresive need for these. The Hungarians became minoriy in the Transylvanian region, and could preserve their community in political unity only by this way. Besides this, it was a necessity to incorporate the 1.6 million Hungarian community in the Romanian political life.

In these circumstances, the Transylvanian Hungarian politics was born at the beginnings of the 1920s, by creating its independent political parties. On 5 June 1921, the Hungarian Peoples' Party (Magyar Néppárt) was established at the initiation of Károly Kós (Mikó 1987: 23), and after a short while, on 12 February 1922, the Hungarian National Party [Magyar Nemzeti Párt] was founded, led by Emil Grandpierre (Toth 2008: 26). But these were only temporary formations. The most important political party of the inter-war period was the National Hungarian Party (Országos Magyar Párt), which started its activity on 28 December 1922, under the leadership of Count Dr György Bethlen. This important party represented the Hungarian minority in the Romanian Parliament for almost two decades (Toth 2008: 99-202).

The new regime of royal dictatorship in Romania, instated in February 1938, transformed the Transylvanian Hungarian political circumstances. The National Hungarian Party, together with all of other political parties in Romania, was dissolved on 31 March 1938 by a royal regulation (Diószegi 1990: 39). Its place was taken over by a new minority formation, which incorporated the whole Hungarian community from Romania without taking into consideration the different political orientations of the people. The leader of this new national organization became the former Hungarian Minister for Foreign Affairs, Count Miklós Bánffy (L. Balogh, 2012). The new formation called Hungarian People's Community (Romániai Magyar Népközösség) was established on 11 February 1939 as the only Hungarian political party in Romania, but without real independence because it was nothing more than a department of the Romanian mass party, the Front of National Renaissance (Frontul Renaşterii Naționale) (Hámori 2004: 69-75).

In this way, when the Second Vienna Award came into effect on 30 August 1940, in Transylvania, there did not exist any regional Hungarian political party, only a centralized, national mass organization without real social and ideological basis. But the idea of a Transylvanian Hungarian independent party with powerful regional characteristics - like Bethlen's National Hungarian Party was - still existed.

Following the German-Italian arbitration on 30 August 1940, the new Hungarian-Romanian border divided the historical Transylvanian region in two in such a way that $47.6 \%$ of its territory was taken under Hungarian rule and the other $52.4 \%$ remained under Romanian control (Korom 1988: 170). The Northern part of Transylvania as well as the Partium, Szeklerland, and Maramureş regions were given back to Hungary (L. Balogh 2002: 5). The total reannexed territory was 43,104 $\mathrm{km}^{2}$ (Thirring 1940: 663), with a very mixed population. According to the 1941 
Hungarian census, there was a Hungarian majority of $52.1 \%$ in a population of 2,557,000 people. The Romanian population comprised 41.5\% (Fogarasi 1944: 4). Besides the 1,380,000 Hungarian inhabitants, there were 1,057,000 Romanians and 44,000 Germans living in this territory (Ablonczy 2011: 47). However, according to Romanian data, $50.2 \%$ of the population was Romanian and only $37.1 \%$ Hungarian (Aurică 1996: 363). We have to mention that at the same time approximately 440,000 Hungarians remained under Romanian rule in Southern Transylvania, from which in half a year after the Vienna Arbitration, until April 1941, almost 80,000 people crossed the new border to Northern Transylvania. In this way, only 363,000 native Hungarians remained in Southern Transylvania, forming 11\% of the whole 3.3 million population of the region (L. Balogh-Bárdi 2008: 162).

In these circumstances, the Hungarian People's Community divided into two, and the local organization of it in Northern Transylvania was soon dissolved. Its Southern Transylvanian part could continue its activity, but only as a social charity organization, without any real political power.

The new borders satisfied neither the Hungarians nor the Romanians. In these circumstances, the division of the historical region of Transylvania, made by great powers without asking the two parts and without resolving the minority issue, could not be a definitive solution to the problem. The territory of Northern Transylvania, with a mainly mixed population, set hard tasks for the Hungarian government as well as for the Transylvanian politicians as to how to organize the political representation of the local population.

It was impossible to hold parliamentary elections because the last ones were held only one year and a few months before, on 28-29 May 1939 (Filep 2008: 155), and the political parties were against new elections in order to preserve their positions (Romsics 2003: 226). The idea of new elections would have favoured only the Hungarian extreme right.

In order to solve the problem, Prime Minister Pál Teleki called for a Cabinet meeting in Budapest on 25 September 1940. They discussed the bill regarding the annexations of the regained territories. They put together a list of names, following the Prime Minister's lead, of those people who would represent Northern Transylvania in the Hungarian Parliament. ${ }^{1}$ The government decided to co-opt the Parliament with political representatives of the re-annexed territories by invitation. This was a solution applied after the former territorial reannexations in 1938 (southern part of Slovakia) and 1939 (region of Subcarpathian Rus - today Zakarpattia Oblast), when the Hungarian Parliament was completed by 38 new deputies, mostly Hungarians from these territories (Dobszay et al. 1998: 144).

Those who were chosen as new Transylvanian deputies were only Hungarians. According to Law XXVI of 1940 (Egry 2008: 29), those invited would be those

1 Teleki, Pál. 1940: Erdélyi feladatok (Transylvanian Duties). Ellenzék, 21 September 1940: LXI. 217: 1-2. 
who had protected successfully the interests of the Hungarians in royal Romania. Thus, the leading politicians of the former National Hungarian Party became members of the Chamber of Deputies in the Hungarian Parliament. Among the fifty Transylvanian Hungarian deputies, twenty seven were former leading members of the National Hungarian Party. Besides György Bethlen, we could mention Dezső Albrecht, István Angi, Árpád Árvay, Artúr Balogh, Ignác Bartha, László Bethlen, Zoltán Bölöni, Gyula Deák, Géza Ember, Albert Figus, József György, Ákos Hinléder-Fels, Gábor Jodál, Ferenc Kölcsey, Gusztáv Kövér, Dezső László, Árpád Paál, Gábor Páll, Károly Pakocs, Ákos Székely, Béla Szentkereszty, Olivér Szilágyi, Ernő Teleki, Mihály Toldalaghy, Andor Török, and Gábor Tusa (Egry 2008: 30). Most of the politicians who had collaborated with the Romanian authorities by taking part in the Hungarian People's Community were left out of the invited deputies. Among them, there were well-known personalities of the Transylvanian Hungarian public life such as Károly Kós or Áron Tamási (Balázs 2003: 300).

The invited group of deputies were young, socially sensitive intellectuals who had effectively activated in the youth movements and had been generally known to reject the extreme right ideas (Balázs 2004: 99). Leading personalities from Transylvanian social-economic organizations were also invited. The most significant among them was Count Béla Teleki, Vice-President of the Transylvanian Hungarian Economic Association [Erdélyi Magyar Gazdasági Egyesület], who became later the leader of the Transylvanian Party (Tibori Szabó 1993: 5). The invited Transylvanian deputies were thus of a mixed type: while some were active politicians, others were young intellectuals or businessmen. At the beginning, the group was disturbed by inner conflicts, mainly because of different views on relationships with the Romanians. Still, the heterogeneous Transylvanian parliamentary panel achieved coherence within a few weeks. The common interest and the enforcement of Northern Transylvanian Hungarian expectations in the Hungarian Parliament pushed into the background the inherited inner conflicts, which were often of a personal character (Murádin 2014: 173).

Besides the fifty seats occupied by Hungarian deputies from Northern Transylvania (Egry 2008: 29-30), the Hungarian government reserved twelve more seats in the Chamber of Deputies for Romanians. But these remained unoccupied. The same situation was repeated in the Upper Chamber, where three seats from the fifteen of Northern Transylvania were reserved for leading Romanian politicians (for example: Iuliu Hossu, Greek Catholic bishop), which also remained unoccupied. During 1941 and 1942, the Hungarian government made some efforts to normalize the situation, but these were rejected every time by the local Romanian leaders, who cited the Romanian government's prohibition as the reason (Ablonczy 2011: 112-113). It has to be mentioned that in the same time the Hungarian community of Southern Transylvania with almost 363,000 people did not have even one deputy in the Romanian 
Parliament. The Hungarian politicians from those territories were not invited at all in the Romanian Chamber of Deputies.

The new Northern Transylvanian deputies occupied their seats in the Hungarian Parliament on $10^{\text {th }}$ October $1940 .^{2}$ At the beginning, they kept away from any Hungarian political party, forming a separate Northern Transylvanian parliamentary group, named officially The Independent Group of Transylvanian Hungarian Deputies (Erdélyi Magyar Képviselők Pártonkívüli Csoportja). ${ }^{3}$ This group consisted the basis of the later Transylvanian Party.

The foundations of the party emerged quickly. The Hungarian government needed a brand new, independent Transylvanian Hungarian party to avoid the Hungarian party competition in Northern Transylvania, a region recently regained and having a very mixed population with a slight Hungarian majority. Prime Minister Pál Teleki wanted to strenghten the Hungarian characteristics of the re-integrated territory, and its main political objective was to unify all the political streams in a collective Hungarian party which would be able to support the politics of the Hungarian government. In this way, it became possible to prevent Northern Transylvanians from organizing extreme right political parties, at first the Arrow Cross Party (Nyilaskeresztes Párt) and the Party of Hungarian Renewal (Magyar Megújulás Pártja) (Szász 2012: 101).

In such circumstances, the foundation of an independent Transylvanian Hungarian political party was not an option, but it became a current political requirement initialized by the Hungarian government. The idea of a brand new Transylvanian Hungarian party was accepted by almost all of the Transylvanian deputies. But, anyway, some of the leading Transylvanian political personalities were against it: Count György Bethlen hoped to reestablish the National Hungarian Party from the Inter-war Period, others, such as Áron Tamási, Dezső Albrecht, or Sándor Vita, tried to create a Transylvanian Hungarian Union based on the idea of 'do not make politics: make social construction!' (Ne politizálj: építkezz!). ${ }^{4}$ None of this was possible to realize because the majority of the Hungarians from Northern Transylvania assumed the idea of a political party, and the government from Budapest made considerable efforts in order to accelerate the process of a new party foundation.

This was carried out in the following way: the Independent Group of Transylvanian Hungarian Deputies simply assumed the name Transylvanian

2 Erdély képviselőit lelkes ünnepléssel fogadta a parlament (The Parliament welcomed the deputies of Transylvania with enthusiastic celebration). Ellenzék, 11 October 1940: LXI. 234: 1.

3 Erdélyi magyar szövetség alakítását kezdeményezik az erdélyi képviselők (The Transylvanian Deputies Initiate the Creation of a Transylvanian Hungarian Union). Ellenzék, 19 November 1940: LXI. 265: 8.

4 Dr Mikó, Imre: Zászlót bontott az Erdélyi Párt (The Transylvanian Party has been established). Ellenzék, 23 December 1940: LXI. 294: 1. 
Party (Erdélyi Párt) at the meeting held between 13 and 15 December $1940,{ }^{5}$ and started to work as a club party (Ablonczy, 2011: 110). Shortly after changing its name, the new political formation built up its system of local organizations in Northern Transylvania between January and May 1941. In this way, the party became a centralized, well-organized political formation, which was created in a unique way, starting out from the Parliament. After all, the Transylvanian Party was highly unusual because it achieved to become part of the Parliament without participating in any of the elections, and its local branches were created by central directives in cooperation with the government from Budapest.

Finally, on 28 May 1941, the Transylvanian Party held its founding general assembly in the capital of Northern Transylvania, Kolozsvár [today: Cluj-Napoca, Romania] (Egry 2008: 35). Here, a party programme was voted and a new, national board of directors was elected. Count Béla Teleki, landlord from Zsibó [today: Jibou, Romania] became the President of the Northern Transylvanian political formation. He was a distant relative of Prime Minister Pál Teleki, who tragically died in the meantime (Ablonczy 2011: 110). Deputy Dezső Albrecht from Bánffyhunyad [today: Huedin, Romania] became the Executive VicePresident of the party; Géza Ember, deputy of Szatmárnémeti [today: Satu Mare, Romania] and József Kolumbán, a lawyer from Csíkszereda [today: Miercurea Ciuc, Romania] were elected as vice-presidents and Deputy Imre Mikó became the general secretary of the Transylvanian Party. ${ }^{6}$

In short time, the party became the most powerful political formation of the eastern part of Hungary. In only a few months, it would dominate ten counties of Northern Transylvania: Szatmár, Szilágy, Bihar, Kolozs, Szolnok-Doboka, Beszterce-Naszód, Maros-Torda, Udvarhely, Csík, and Háromszék. The Northern Transylvanian Hungarians joined the new political formation in large numbers starting from January 1941. The members represented all social classes from the land-owning aristocracy to the middle classes of towns, through the tradesmen and from the working classes to the peasants.

By the founding general assembly in May 1941, the number of party members reached 200,000, ${ }^{7}$ and the maximum was reached in January 1942, when the Party had 700 local branches and 243,500 active members (Egry 2008: 44). In December 1943, the Transylvanian Party still had 231,181 members. ${ }^{8}$ All the social strata

5 Három napig tartó értekezleten határozták el az erdélyi képviselők az >>Erdélyi Párt<< megalakítását (The Transylvanian Deputies Decided the Creation of the ‘Transylvanian Party' in a Three Days' Meeting). Ellenzék, 17 December 1940: LXI. 289: 8.

6 Megválasztották a párt országos vezetőségét (The National Leadership of the Party Was Elected). Kolozsvári Estilap, 28 May 1941: IX. 121: 6.

7 Ibidem.

8 Magyar Nemzeti Levéltár. Országos Levéltár (Hungarian National Archives. State Archives - in continuous: HNA. SA). Teleki Béla iratai 1942-1944 (Documents of Béla Teleki 1942-1944). P 2256. 117. 1. 143. 'Dr Páll György fótitkár jelentése Teleki Béla pártelnöknek' (The Report of General Secretary Dr György Páll to Party Leader Béla Teleki). Cluj, 9 December 1943: 1. 
of the Hungarians of the region were represented in the Transylvanian Party, whose sometimes contrary interests had a disruptive force (Balázs 2003: 329330). Thus, the Transylvanian Party had to make compromises, which made the activity of this political formation more difficult and contributed to the decrease of its flexibility. Even so, the Party was held together by its regional identity, the solidarity of the Transylvanian Hungarians seasoned during minority existence, its Transylvanian viewpoint, which was more sensible to social relationships than the Hungarians in general, and, last but not least, the common demand to rebuild and revitalize the Hungarian character of Transylvania.

The Party was a unique political formation in Hungarian political history. Not only by the special circumstances in which it had been established and not only by its unusual formation process, starting directly from the Chamber of Deputies. It was a special political formation because it was a traditional political party and it functioned as an interest group at the same time. The source of the Party's internal dilemma was that it could not decide whether to be a simple party or a national political organization. Further, it was the only political party of the Hungarians of Transylvania which had been founded in a majority period - from a Hungarian point of view - in Transylvania in the whole of the $20^{\text {th }}$ century. No other Hungarian political party has had such great possibilities in Transilvania to realize their political programme as the Transylvanian Party. Due to the government's support, immediately after its founding, the Party became an organic part of the national political life. Meanwhile, it preserved a lot of regional Transylvanian characteristics based on local political traditions. At the beginning, the Transylvanian Party had three principal roles: to hold together the Northern Transylvanian Hungarians, to represent Northern Transylvanians in the Hungarian Parliament, and to mediate between the local Hungarian, Romanian, German, and Jewish populations and the Hungarian government. Based on these roles, the Transylvanian Party proposed three elementary objectives. These were:

1.) To preserve the political, economic, and cultural unity of the Hungarians in Transylvania;

2.) To rebuild Transylvania in co-operation with the Hungarian government and connect it into the single national circulation;

3.) To serve Hungary's inner change and strengthen it with Transylvanian mentality. ${ }^{9}$

The most important task of the Party was to help the government in its efforts to establish a new, effective minority policy in order to relieve the interethnic

9 Magyar reformot! Gróf Teleki Béla beszéde az Erdélyi Párt kolozsvári és Kolozs vármegyei tagozatainak 1943. szeptember hó 12-én, Kolozsváron tartott nagyválasztmányi gyúlésén (Hungarian Reform! Discourse of Count Béla Teleki at the Committee Meeting of the Transylvanian Party's Local Branch of Cluj and County Branch of Cluj Held on 12 September 1943 in Cluj). Kolozsvár: az Erdélyi Párt kiadása. 1943: 16. 
tensions of the re-annexed territories. The leaders of the Transylvanian Party, in their concepts and actions on minority issues, often based on their own minority experiences from the period of Romanian rule in the inter-war period, serving as negative models not to be followed. These covered: exclusion of minorities from the political life of the country, impediment of their development, and forced assimilation. Such measures proved to be no solution to the minority problem. That is why the Transylvanian Party worked out new, more effective modalities of a functional minority policy. On the one hand, the inclusion of minorities in the Hungarian political nation and, on the other hand, the consolidation of the Hungarian nation itself in every possible way - political, economic, cultural, and demographic - in order to speed up the natural assimilation process by reenforcing the attractiveness of the Hungarian nation. ${ }^{10}$

The Transylvanian Party incorporated the majority of the Northern Transylvanian deputies in the Hungarian Parliament between 1940 and 1944. From those 50 deputies invited from the Transylvanian territories re-encorporated by Hungary in 1940, 36 became deputies of the Transylvanian Party. They formed together $9.75 \%$ of the whole Chamber of Deputies with 369 members. After the Party of Hungarian Life (Magyar Élet Pártja), the governing political power, which had 214 mandates in May 1941, occupying 58\% of the seats in Chamber of Deputies, the Transylvanian Party became the second political party in the Hungarian Parliament immediately after its establishment.

Its relative power in the Hungarian political life had some negative aspects too: it gives an important impetus for the governing party to integrate the Transylvanian Party, putting an end to its independence. Prime ministers László Bárdossy and Miklós Kállay, who were at the same time leaders of the Party of Hungarian Life, tried to reinforce their party with the incorporation of the 'intractable' Transylvanian Party with all of its quarter of a million members (Tibori Szabó 1993: 16). The party fusion could be avoided by the Transylvanian Party, but not the political alliance with the governing party. It was signed on 3 February 1942 in Budapest. ${ }^{11}$

In spite of this close relation with the Party of Hungarian Life, the Transylvanian Party still had primarily Transylvanian characteristics. Its deputies held their speeches in the Parliament mostly on Transylvanian issues: inter-ethnic relations (the situation of the Romanian minority in Northern Transylvania), economic problems (agriculture, industry, trade), infrastructural investments in Northern Transylvania, and especially in Szeklerland (road and railway constructions), social issues (situation of the pensioners), Hungarian cultural politics in

10 Erdély a magyar Képviselóházban II (Transylvania in the Hungarian Chamber of Deputies II). Kolozsvár: az Erdélyi Párt kiadása. 1943: 42.

11 HNA. SA. Teleki Béla iratai 1942-1944 (Documents of Béla Teleki 1942-1944). P 2256. 117. 1. 1. Állásfoglalás [Standpoint]. 3 February 1942: 1. 
multiethnic regions of Hungary, special educational problems in Northern Transylvania (the situation of the Hungarian university in Kolozsvár (ClujNapoca), state grants for the confessional schools), and the implementation of a main administrative reform. At the level of forreign politics, the Transylvanian Party urged Hungarian-Romanian international negotiations on improving the situation of the Hungarian minority in Southern Transylvania, having remained part of Romania after 1940, and of the Romanian minority under Hungarian rule in Northern Transylvania. The party's deputies tried to influence the relations of Hungary with Germany and Italy, the great powers who signed the Second Vienna Award. ${ }^{12}$

Besides its parliamentary activity, the Transylvanian Party made an institutional connection between the local Hungarian political leaders from Northern Transylvania and the Hungarian government. It was in close relation with ministries, and especially with the Prime Minister's Office, which helped it in the transmission of the local, Transylvanian expectations toward the government. Sometimes the party's interventions were succesful, mostly in special cases, like clerical salaries, state grants for confessional schools, etc., ${ }^{13}$ but in really hard problems, as the general national administrative reform was, the party's influence proved to be insufficient (Tibori Szabó 1993: 15).

The situation of the Transylvanian Party, during all of its four years of functioning, was very delicate. Using the words of Count Béla Teleki, the President of the Party, until the German occupation, the party's situation 'was hard, and then hopelessly impossible’ (Tibori Szabó 1993: 16). After losing its remaining sovereignity, as a result of the German aggression on 19 March 1944, Hungary was ruled by the puppet government of Döme Sztójay, former Ambassador to Berlin, which followed Hitler's directives (Romsics 2003: 262). These new conditions put the Transylvanian Party into a very difficult situation. The Party divided into two. Many politicians of the party, led by Sándor Vita and Count Béla Teleki, stepped aside and gave up their parliamentary seats. But other Transylvanian Party deputies, lead by Dezső Albrecht, carried on their work in the Parliament and consistently supported the steps taken by the government. The transformation of the country in a veritable battlefield in late summer 1944, followed by the general suspension of the political activities, ${ }^{14}$ made the functioning of the Transylvanian

12 Erdély a magyar Képviselöházban (Transylvania in the Hungarian Chamber of Deputies). Kolozsvár: az Erdélyi Párt kiadása. 1942; Erdély a magyar Képviselöházban II (Transylvania in the Hungarian Chamber of Deputies II). Kolozsvár: az Erdélyi Párt kiadása. 1943; Erdély a magyar Országgyúlésen (Transylvania in the Hungarian Parliament). Kolozsvár: az Erdélyi Párt kiadása. 1944.

13 Az Erdélyi Párt elnöksége a miniszterelnöknél és a kultuszminiszternél (The Presidency of the Transylvanian Party at the Prime Minister, and the Minister of Culture). Kolozsvári Estilap, 14 August 1941: IX. 183: 5.

14 HNA. SA. Teleki Béla iratai 1942-1944 (Documents of Béla Teleki 1942-1944). P 2256. 117. 1. 268. 634/1944. Bizalmas tájékoztató (Confidential Information). 8 June 1944: 1. 
Party impossible. It became unable to coordonate its everyday relation with the party members, and the local branches became unoperational. Finally, the decree regarding the dissolution of all political parties issued on 24 August 1944, the second day after Romania changed sides (Ablonczy 2011: 114), led to the total disintegration of the Transylvanian Party.

Taking into consideration that the Transylvanian Party had a very short time of activity, the following question can be asked: does it have any importance to research its history or it has no significance? Has it left behind any political heritage or not? In my oppinion, the Transylvanian Party was an important political formation, which had to be researched. Although it functioned only for four years, it has a great political heritage, which can be classified into five points:

1. Sustenance of the most important Transylvanian regional political traditions after the integration of the territory into the Hungarian state. This means more tolerant minority politics and high-level social sensibility.

2. The idea of realizing an absolute Transylvanian Hungarian political union, with main local characteristics.

3. Need of general social reform realized in a constitutional way.

4. Permanent communication with the Romanian population of Transylvania, in order to reach ethnic conciliation.

5. Abolition of barriers between different social classes and establishment of a truly unified Hungarian nation in order to stop the spread of extreme left or right political ideologies.

These made the Transylvanian Party worthy to research. During the communist age, this was impossible because the Party was seen as one that functioned in 'fascist times'... Until 1989, it was almost forgotten, and unfortunately today it is already impossible to bring it back in all of its aspects. The research work on this theme needs interdisciplinarity. The party could be studied with different methods used in research work in history, anthropology, and sociology. It is important to research into the party's ideology, its parliamentary representation, institutional history, the main characteristics of its leaders, and the different social groups represented in its membership. Realizing the Party's chronology is one of the most interesting tasks. But at the same time it is important to research the Transylvanian Party's relations with other political formations of those times. Some special research works on the Party's minority politics could lead to interesting results.

The study of the Transylvanian Party is quite difficult. Most of the archival data disappeared or were destroyed during the Second World War, and the method of oral history could not be used because of the long time passed since the existence of the Party. In spite of these, a research work is possible by using sporadic archival data and the minutes of the Chamber of Deputies as well as the Party's brochures and the memoirs of its political leaders. The contemporary 
Hungarian press, and in some special aspects the on-line databases, proved to be very useful sources.

The realization of a sufficiently detailed research work on the topic of the Transylvanian Party is still a debt to be paid to the Hungarian community of Transylvania. Hopefully, the publication of the author's new book entitled The History of the Transylvanian Party between 1940 and 1944 will pare down this debt, at least partially.

\section{References}

\section{Archive Sources}

Magyar Nemzeti Levéltár. Országos Levéltár (Hungarian National Archives. State Archives).

Teleki Béla iratai 1942-1944 (Documents of Béla Teleki 1942-1944). P 2256. 117. 1.: Állásfoglalás (Standpoint). 3 February 1942: 1.

Dr. Páll György fótitkár jelentése Teleki Béla pártelnöknek (The Report of General Secretary Dr György Páll to Party Leader Béla Teleki). Kolozsvár. 9 December. 1943: 1.

Bizalmas tájékoztató (Confidential information). 8 June 1944: 1.

\section{Publications of the Transylvanian Party}

Erdély a magyar Képviselóházban (Transylvania in the Hungarian Chamber of Deputies). Kolozsvár: az Erdélyi Párt kiadása. 1942.

Erdély a magyar Képviselóházban II (Transylvania in the Hungarian Chamber of Deputies II). Kolozsvár: az Erdélyi Párt kiadása. 1943.

Erdély a magyar Országgyúlésen (Transylvania in the Hungarian Parliament). Kolozsvár: az Erdélyi Párt kiadása. 1944.

Magyar reformot! Gróf Teleki Béla beszéde az Erdélyi Párt kolozsvári és Kolozs vármegyei tagozatainak 1943. szeptember hó 12-én, Kolozsváron tartott nagyválasztmányi gyúlésén (Hungarian Reform! Discourse of Count Béla Teleki at the Committee Meeting of the Transylvanian Party's Local Branch of Cluj and County Branch of Cluj Held on 12 September 1943 in Cluj). Kolozsvár: az Erdélyi Párt kiadása. 1943.

\section{Specialized Books}

ABLONCZY, Balázs. 2011. A visszatért Erdély 1940-1944 (Transylvania Rejoining 1940-1944). Budapest: Jaffa. 
AURICĂ, Simion. 1996. Dictatul de la Viena (The Vienna Arbitration). Second edition. Bucharest: Albatros.

BALÁZS, Sándor. 2003. Mikó Imre. Élet- és pályakép. Kéziratok, dokumentumok (1933-1968) (Imre Mikó. Life and Career. Manuscripts, Documents (19331968)). Cluj-Napoca: Polis.

DOBSZAY, Tamás-ESTÓK, János-SALAMON, Konrád-SZERENCSÉS, KárolyTOMBOR, László (eds). 1998: Tisztelt Ház! A magyar országgyúlések története 1848-1998 (Honourable Deputies! The history of the Hungarian Parliaments 1848-1998). (Budapest): Puskás Tivadar Távközlési Technikum.

EGRY, Gábor. 2008. Az erdélyiség „színeváltozása”. Kísérlet az Erdélyi Párt ideológiájának és identitáspolitikájának elemzésére 1940-1944 (The Transformation of Transylvanianism. A Way of Analysing the Ideology and Identity Politics of the Transylvanian Party 1940-1944). Budapest: Napvilág Kiadó.

L. BALOGH, Béni. 2002. A magyar-román kapcsolatok 1939-1940-ben és a második bécsi döntés (The Hungarian-Romanian Relations in 1939-1940 and the Second Vienna Arbitration). Csíkszereda: Pro-Print Könyvkiadó.

MIKÓ, Imre. 1987. Huszonkét év. Az erdélyi magyarság politikai története 1918. december 1-tól 1940. augusztus 30-ig (Twenty-Two Years. The Political History of the Hungarians Living in Transylvania from 1 December 1918 to 30 August 1940). Budapest: the edition of 'Studium', 1941. Reedited in Bern: Európai Protestáns Magyar Szabadegyetem.

ROMSICS, Ignác. 2003. Magyarország története a XX. században (The History of Hungary in the $20^{\text {th }}$ Century). Budapest: Osiris Kiadó.

TIBORI SZABÓ, Zoltán. 1993. Teleki Béla erdélyisége. Embernek maradni embertelen idókben (The Transylvanianism of Béla Teleki. Remaining Human in Inhuman Times). Kolozsvár: Nis Kiadó.

TOTH, Szilárd. 2008. Partidul Maghiar şi problema minorității maghiare în parlamentul României în perioada interbelică. (The Hungarian Party and the Problem of the Hungarian Minority in the Romanian Parliament in the Interwar Period). Cluj-Napoca: Editura Argonaut.

\section{Studies}

BALÁZS, Sándor. 2004. László Dezső a magyar parlamentben (Dezső László in the Hungarian Parliament). In: Cseke, Péter (ed.), László Dezsố emlékezete 19042004 (The Memory of Dezső László 1904-2004). Kolozsvár: Polis Könyvkiadó: 99-122.

L. BALOGH, Béni. 2012. Csapdahelyzetben. Romániai magyar érdekképviselet 1940-1944 között. (Entrapped. The Representation of Hungarians' Interests 
in Romania between 1940-1944). http://itthon.transindex.ro/?cikk=16305 (Accessed on: 21 October 2016).

L. BALOGH, Béni-BÁRDI, Nándor. 2008. A dél-erdélyi magyarság jogi és politikai helyzete a második bécsi döntést követően (The Legal and Political Situation of the Hungarians Living in Southern Transylvania after the Second Vienna Award). In: Bárdi, Nándor-Fedinec, Csilla-Szarka, László (eds), Kisebbségi magyar közösségek a 20. században (Hungarian Minority Communities in the $20^{\text {th }}$ Century). Budapest: Gondolat Kiadó-MTA Kisebbségkutató Intézet, 162-167.

DIÓSZEGI, László. 1990. A romániai magyarság története 1919-1940 (The History of the Hungarians of Romania 1919-1940). In: Diószegi, László-R. Süle Andrea (eds), Hetven év. A romániai magyarság története 1919-1989 (Seventy Years. The History of the Hungarians of Romania 1919-1989). Budapest: Magyarságkutató Intézet, 11-44.

FILEP, Tamás Gusztáv. 2008. A „visszatért” magyarok és nem magyarok beilleszkedése, jogi helyzetük és magatartásuk (The Integration of the 'Returned' Hungarians and Non-Hungarians, Their Legal Situation and Attitude). In: Bárdi, Nándor-Fedinec, Csilla-Szarka, László (eds), Kisebbségi magyar közösségek a 20. században (Hungarian Minority communities in the $20^{\text {th }}$ century). Budapest: Gondolat Kiadó-MTA Kisebbségkutató Intézet, 154-161.

FOGARASI, Zoltán. 1944. A népesség anyanyelvi, nemzetiségi és vallási megoszlása törvényhatóságonkint 1941-ben (The Diversity of the Population by Mother Tongue, Nationality, and Religion in Every Municipality in 1941). Magyar Statisztikai Szemle 1-3: 3-9.

HÁMORI, Péter. 2004. Magyar társadalomszervezési kísérletek Észak-Erdélyben (1938-1944) (Hungarian Social Organization Attempts in Northern Transylvania (1938-1944)). In: Korall 10(18): 69-73. http://adatbank.transindex.ro/html/ cim_pdf972.pdf (Accsessed on: 21 October 2016).

KOROM, Mihály. 1988. A második bécsi döntéstől a fegyverszünetig (From the Second Vienna Award to the Armistice). In: Rácz, István (ed.), Tanulmányok Erdély történetéról (Studies on the history of Transylvania). Debrecen: Csokonai Kiadó, 170-176.

MURÁDIN, János Kristóf. 2014. Being in Minority or Majority? The Transylvanian Party in the Hungarian Public Life Between 1940 and 1944. In: Horváth, IstvánSzékely, Ibolya-Székely, Tünde-Tonk, Márton (eds), Minority Representation and Minority Language Rights. Cluj-Napoca: Scientia Publishing House-The Romanian Institute for Research on National Minorities, 171-187.

SZÁSZ, István Tas. 2012. Pillantás az Erdélyi Magyar Gazdasági Egyesület utolsó éveire (Overview of the Last Years of the Transylvanian Hungarian Economic Society). Korunk XXIII(11): 100-106. 
THIRRING, Lajos. 1940. A visszacsatolt keleti terület. Terület és népesség (The Re-Annexed Eastern Territory. Territory and Population). Magyar Statisztikai Szemle 8-9: 663-667.

\section{Press Articles}

\section{Ellenzék}

Erdély képviselőit lelkes ünnepléssel fogadta a parlament (The Parliament Welcomed the Deputies of Transylvania with Enthusiastic Celebration). 11 October 1940: LXI. 234: 1.

Erdélyi magyar szövetség alakítását kezdeményezik az erdélyi képviselők (The Transylvanian Deputies Initiate the Creation of a Transylvanian Hungarian Union). 19 November 1940: LXI. 265: 8.

Három napig tartó értekezleten határozták el az erdélyi képviselók az >>Erdélyi Párt $<<$ megalakítását (The Transylvanian Deputies Decided the Creation of the 'Transylvanian Party' in a Three Days' Meeting). 17 December 1940: LXI. 289: 8.

MIKÓ, Imre Dr. 1940. Zászlót bontott az Erdélyi Párt (The Transylvanian Party Has Been Established). 23 December 1940: LXI. 294: 1.

TELEKI, Pál. 1940. Erdélyi feladatok (Transylvanian Duties). 21 September 1940: LXI. 217: 1-2.

Kolozsvári Estilap

Az Erdélyi Párt elnöksége a miniszterelnöknél és a kultuszminiszternél (The Presidency of the Transylvanian Party at the Prime Minister and the Minister of Culture). 14 August 1941: IX. 183: 5.

Megválasztották a párt országos vezetőségét (The National Leadership of the Party Was Elected). 28 May 1941: IX. 121: 6. 